\title{
A Serological Study on Infection Patterns, Control and Persistence of Classical Swine Fever in Infected Farms in the Philippines
}

\author{
P. GEERTS, M. PENSAERT, and R. SANCHEZ ${ }^{1)}$
}

Faculty of Veterinary Medicine, University of Ghent, Salisburylaan 133, 9820 Merelbeke, Belgium, "College of Veterinary Medicine, University of the Philippines at Los Banos, 4031 Laguna, Philippines

(Received 23 February 1995/Accepted 9 July 1995)

\begin{abstract}
In 3 farrow-to-finish farms with enzootic classical swine fever (CSF) all sick pigs were culled and an intensive vaccination programme was introduced. Boars and sows were vaccinated every 6 months and piglets at the age of 6 and 8 weeks. The infection was monitored on clinical grounds and by means of serological examination of the farms. Serological results reflected well the clinical situation in the farms. High titers and a high percentage of animals with positive titers were observed in infected farms, compared to lower titers in a clinically "free" farm, which were interpreted as titers due to vaccination. Although clinical improvement was noticed, the rigid vaccination regime was not able to control CSF in none of the farms. In all cases, a small percentage of pigs in the finishing stage was still affected. Since these pigs seemed not to have responded to vaccination at 6 and 8 weeks of age, the programme was questioned. Additionally, very high titers were recorded in sows from infected farms, which would automatically extend the period of passive protection in offspring and postpone the age at which piglets could be vaccinated. More intensive programmes, which include also vaccination beyond the age of 8 weeks, were suggested to bring enzootic infections under control.-KEY wORDs: classical swine fever, enzootic infection, serology, vaccination.
\end{abstract}

J. Vet. Med. Sci. 57(5): 917-920, 1995

Classical swine fever (CSF) is enzootic on many large scale swine farms in the Philippines. In spite of vaccination, the virus commonly causes protracted problems of malperformance among 10 to $30 \%$ of pigs between the age of 7 to 16 weeks. The disease is chronic and major signs are inappetence, respiratory dyspnoea and sometimes diarrhoea. Vaccines are readily available and vaccination is farm routine. Breeding animals are vaccinated before or after each farrowing. Offspring is generally vaccinated once or twice before or at the age of 6 weeks. Earlier studies have shown that vaccination of pigs from immune mothers with modified live vaccines carried out at the age of 6 weeks results in $80 \%$ immune animals $[3,6,7]$. However, serological studies in the framework of vaccination campaigns in the Netherlands proved that 50 to $70 \%$ of the piglets born from vaccinated dams fail to develop a protective serological response against CSF when vaccinated before 7 weeks of age. For this reason the age of vaccination had been raised to 7 to 9 weeks, which offered better "take" of the vaccine [8]. Still, under enzootic conditions like in the Philippines, a vaccination program which offers protection in a maximum number of pigs until market weight may be very different.

In a first part of this study, piglets in enzootically infected farms were intensively vaccinated at the age of 6 and 8 weeks and the infection status of CSF was monitored by means of serological examination. Although an exact differentiation between vaccinated and infected animals is not possible, infection was concluded on the height of titers in a group of pigs, since antibody titers are lower after vaccination than after infection $[1,2,5,9]$.

The second part of this study describes a longitudinal serological follow-up of the evolution of the $\mathrm{SN}$ titer in pigs sampled at different intervals between the suckling stage and marketing, in an effort to detect at what age pigs eventually become infected with field virus. The serological work performed in this study also offered an opportunity to evaluate to what extend a serological profile of a swine herd can learn about its CSF infection status.

\section{MATERIALS AND METHODS}

\section{Design of the field study}

1. Transversal study in 3 infected farms.

In 3 farms ( $A, B$ and $C$ ) CSF was confirmed by immunofluorescence technique. Farm $A$ had 70 sows, whereas farms $B$ and $C$ were large scale operations with 800 and 1,000 sows respectively. The morbidity in farms A and $\mathrm{B}$ was around $30 \%$ in 7 to 16 weeks old pigs and in farm $\mathrm{C}$ around $20 \%$ in 12 to 16 weeks old pigs. In all farms similar clinical situations had occurred in the past and vaccination against CSF was carried out in piglets at the age of 3 to 6 weeks. Breeders were vaccinated twice a year. At the start of the study, all sick pigs were culled and a new vaccination programme against CSF was implemented. Sows and boars were vaccinated every 6 months and pigs at the age of 6 and 8 weeks. For every 10 pigs another needle was used to avoid eventual transmission of field virus. The vaccine used was a tissue cultured chinese strain (Pestiffa, Rhone Merieux). After installation of the rigid vaccination programme, the epidemiological situation was followed during 1 year. Every 2 months, a clinical evaluation was made. Additionally, blood samples were collected from 25 randomly selected fattening pigs at market weight for determination of titers against CSF. 
2. Longitudinal serological study.

Parallel to the first part of this study, a longitudinal serological study was performed in the same farms. A fourth farm, designated $D$, which gave no clinical indications of a CSF infection in the present or the past, was included in this study. The vaccine used and the programme applied were the same as in the other farms. On farms A, B and D, 4 piglets per litter were identified and blood was collected at the age of 4 weeks. At the same time, blood was collected from their mother. Subsequently, blood samples were collected from the same pigs at the age of $7,10,13$ and 23 weeks, which is the marketing age. In farm A, 3 litters were followed, in farm B and D, 5 litters. Because CSF was diagnosed in pigs older than 12 weeks in farm $\mathrm{C}, 40$ pigs were identified at 10 weeks and blood was collected at $10,13,16$ and 23 weeks. In addition, blood was collected from 15 sows in this farm to assess the height of immunity transferred to newly born piglets.

\section{Seroneutralisation test}

Twofold dilutions of serum samples were examined by means of a seroneutralisation (SN) test using PK15 cells according to Liess and Prager [4]. Briefly, $50 \mu \mathrm{l}$ of every dilution were incubated with $200 \mathrm{TCID}_{50}$ Alfort 187 strain in $50 \mu \mathrm{l}$. After incubation for $1 \mathrm{hr}$ at $37^{\circ} \mathrm{C}, 20,000 \mathrm{PK} 15$ cells in $100 \mu \mathrm{l}$ were added per well. After incubation for 4 days, monolayers were stained with an indirect immunoperoxidase reaction. Titers were expressed as $\log _{2}$ of the reciprocal of the highest serum dilution which totally inhibited virus growth.

\section{RESULTS}

1. Transversal study.

1.1 Clinical improvement.

In farm A, no clinical case of CSF was detected anymore at 2 months after the start of the intensive vaccination programme. In farm $B$ the number of sick pigs decreased systematically and after 5 months no signs of CSF were observed anymore. In both farms, the spreading of the virus was confirmed again 12 months after the start of the study in pigs older than 12 weeks. Around $20 \%$ had lost appetite and showed respiratory dystress. Farm $\mathrm{C}$ continued to have problems in 10 to $25 \%$ of the fattening pigs throughout the study.

\subsection{Serological results.}

Table 1 shows the evolution of the $\%$ of animals with antibodies, the geometrical mean titer (GMT) and the range of titers in 25 randomly selected fattening pigs sampled over a period of 1 year. Samples collected at 2, 4, 8 and 10 months in farm $\mathrm{C}$ were not examined since this would not have furnished extra information.

\section{Longitudinal serological study.}

Table 2 shows the evolution in GMT $\left(\log _{2}\right)$ of pigs sampled at different ages and their sows in farms A, B and D. In farm A titers decreased gradually and at market weight titers were very low to nihil. In farm B seroconversion was noticed. The highest titer recorded was $\geqq 10$ at 23 weeks (litter 2). The last sampling in this farm took place at the time CSF was reconfirmed. At 23 weeks 2 pigs had died (or been culled) in litter 2, and 1 in litter 3 and 4. In farm $\mathrm{D}$ seroconversion was noticed and the highest titer recorded was 6 at 23 weeks (litter 4).

Table 3 shows the serological results in farm C. In this farm, 2 pigs had died at 16 weeks and 11 at 23 weeks. The 15 sows examined in this farm had a GMT $\left(\log _{2}\right)$ of $\geqq 7.9$ and a range of $5-\geqq 10$.

\section{DISCUSSION}

Serological screening of a swine herd for CSF proves useful to monitor an infection, even under enzootic conditions where vaccination is practised. In this study serological results are well in accordance with clinical

Table 1. Results of serological examination of fatteners in farms A, B and C over a period of 12 months

\begin{tabular}{|c|c|c|c|c|c|c|c|c|}
\hline & \multirow[b]{2}{*}{ Months } & \multicolumn{7}{|c|}{$\begin{array}{l}\% \text { of animals with antibodies, GMT }\left(\log _{2}\right) \text { and range of titers }\left(\log _{2}\right) \text { at start } \\
\text { and at } 2,4,6,8,10 \text { and } 12 \text { months after starting the intensive vaccination. }\end{array}$} \\
\hline & & 0 & 2 & 4 & 6 & 8 & 10 & 12 \\
\hline \multirow[t]{3}{*}{ Farm A } & $\%$ & 100 & 100 & 28 & 36 & 68 & 44 & 68 \\
\hline & GMT & $\geq 7.7$ & 7.3 & 4.8 & 3.8 & 3.9 & 3.4 & $\geqq 6$ \\
\hline & Range & $5-\geqq 10$ & $4-9$ & $3-5$ & $3-5$ & $2-7$ & $2-6$ & $2-\geqq 10$ \\
\hline \multirow[t]{3}{*}{ Farm B } & $\%$ & 100 & 100 & 84 & 44 & 52 & 72 & 96 \\
\hline & GMT & $\geqq 7.2$ & 6.9 & $\geqq 5.6$ & 5.4 & 4.1 & 5.1 & $\geqq 5.9$ \\
\hline & Range & $3-\geqq 10$ & $3-9$ & $3-\geqq 10$ & $3-9$ & $2-8$ & $2-6$ & $2-\geqq 10$ \\
\hline \multirow[t]{3}{*}{ Farm C } & $\%$ & 96 & NT & NT & 84 & NT & NT & 80 \\
\hline & GMT & $\geqq 7.1$ & NT & NT & $\geqq 6.7$ & NT & NT & $\geqq 6.7$ \\
\hline & Range & $4-\geq 10$ & NT & NT & $3-\geqq 10$ & NT & NT & $2-\geqq 10$ \\
\hline
\end{tabular}

NT: Not tested. 
Table 2. Results of serological examination of pigs at different ages and their mother in farms A, $\mathrm{B}$ and $\mathrm{D}$

\begin{tabular}{|c|c|c|c|c|c|c|c|c|}
\hline & & & \multicolumn{6}{|c|}{$\begin{array}{l}\text { GMT }\left(\log _{2}\right) \text { and range of titers }\left(\log _{2}\right) \text { in sows and } 4 \text { pigs per litter at } \\
\text { the age of: }\end{array}$} \\
\hline & & & Sow & 4 weeks & 7 weeks & 10 weeks & 13 weeks & 23 weeks \\
\hline & \multicolumn{8}{|c|}{ Litter } \\
\hline \multirow{6}{*}{ Farm A } & 1 & GMT & 9.3 & 6.5 & 4.5 & 2.9 & NT & 1 \\
\hline & & Range & & $6-7$ & $4-5$ & $2-3$ & & $0-2$ \\
\hline & 2 & GMT & 9.7 & 6 & 5 & 3 & NT & 0 \\
\hline & & Range & & $6-6$ & $4-6$ & $2-4$ & & \\
\hline & 3 & GMT & 9.7 & 6.9 & 4.4 & 3 & NT & 1 \\
\hline & & Range & & $6-7$ & $2-5$ & $0-4$ & & $0-2$ \\
\hline \multirow[t]{10}{*}{ Farm B } & 1 & GMT & 3 & 2 & 0 & NT & NT & 4.2 \\
\hline & & Range & & $0-4$ & & & & $3-5$ \\
\hline & 2 & GMT & 9 & 5.3 & 3.9 & 2.1 & 1 & $\geqq 8.1$ \\
\hline & & Range & & $5-6$ & $3-4$ & $2-3$ & $0-2$ & $5-\geqq 10$ \\
\hline & 3 & GMT & 5 & 3.4 & 2.2 & 0 & 1 & 5 \\
\hline & & Range & & $3-4$ & $2-3$ & & $0-2$ & $4-6$ \\
\hline & 4 & GMT & 6 & 3.4 & 2 & 2 & 5 & 5.1 \\
\hline & & Range & & $3-4$ & $0-3$ & $2-2$ & $5-5$ & $3-6$ \\
\hline & 5 & GMT & 9 & 5 & 3.4 & NT & NT & 2 \\
\hline & & Range & & $5-5$ & $3-4$ & & & $0-4$ \\
\hline \multirow[t]{10}{*}{ Farm D } & 1 & GMT & 8 & 5.4 & 3.4 & NT & NT & 3.3 \\
\hline & & Range & & $5-6$ & $3-4$ & & & $0-4$ \\
\hline & 2 & GMT & 8 & 5.9 & 4 & NT & NT & 1.6 \\
\hline & & Range & & $5-6$ & $4-4$ & & & $0-2$ \\
\hline & 3 & GMT & 5 & 4.2 & 1 & NT & NT & 3.9 \\
\hline & & Range & & $3-5$ & $0-2$ & & & $3-4$ \\
\hline & 4 & GMT & 3 & 1.6 & 1 & NT & 3.3 & 5.3 \\
\hline & & Range & & $0-2$ & $0-2$ & & $2-5$ & $3-6$ \\
\hline & 5 & GMT & 3 & 3 & 1.6 & NT & NT & 2 \\
\hline & & Range & & $3-3$ & $0-2$ & & & $0-4$ \\
\hline
\end{tabular}

NT: Not tested.

Table 3. Results of serological examination of 40 fatteners at different ages in farm $\mathrm{C}$

\begin{tabular}{lcccc}
\hline & \multicolumn{4}{c}{$\begin{array}{l}\text { \% of animals with antibodies, GMT }\left(\log _{2}\right) \text { and } \\
\text { range of titers }\left(\log _{2}\right) \text { in }\end{array}$} \\
& $\begin{array}{l}\text { 40 pigs at the age of: } \\
\text { 10 weeks }\end{array}$ & 13 weeks & 16 weeks & 23 weeks \\
\hline$\%$ & 65 & 80 & 92 & 89 \\
GMT & 2.9 & 4.2 & 5.2 & $\geqq 6.9$ \\
Range & $2-9$ & $2-8$ & $2-8$ & $2-\geqq 10$ \\
\hline
\end{tabular}

observations in all farms. A CSF infection in the farm is reflected by a high GMT in a group of pigs and high titers in individual pigs, which can not be induced by vaccination with the type of vaccine used. Titers in the clinically "free" farm $D$ correspond with vaccination titers obtained in other studies. At 6 to 8 weeks after vaccination with a chinese strain, seroneutralisation ( $\mathrm{SN}$ ) titers, expressed as $\log _{2}$, are reported to range between 0 and 8 , with an average titer of $5[1,5,9]$. Serological examination of 30 pigs during an outbreak of CSF resulted in a mean SN titer $\left(\log _{2}\right)$ of $\geqq 7.4$ and a range of 0 to $\geqq 9$. Seven animals had remained without serological response [2]. Also in our study some animals do not develop an antibody response in the presence of field virus. This is a normal observation after vaccination, as well as after infection, and seems to reflect few and slow dissemination of virus through the farm and low virus infectivity. The proposed vaccination programme, i.e. vaccination of piglets at the age of 6 and 8 weeks, was not able to clinically control CSF in none of the farms, though it initially gave the impression of being effective in farm A and $B$. In farm $A$ the clinical situation normalised very rapidly. For farm $B$ it took a few months longer, which can be related to the farm scale. In both farms, CSF was confirmed again after 1 year, only in $20 \%$ of fattening pigs. CSF infection in fatteners has been a continuous observation in farm C. Conclusively, double vaccination at 6 weeks and 8 weeks does not protect all pigs until market weight under given enzootic circumstances.

High titers, which can not be related to vaccination, were recorded in sows in all three farms with chronic CSF. Maternal immunity interferes with successful vaccination of piglets born from immune dams, and piglets born from sows with extreme high titers will experience prolonged interference with vaccination. Many of the fatteners sampled during the time of clinical recovery in farms A and 
B had remained without titer, suggesting low "take" of the double vaccination.

Under enzootic conditions, the effect of vaccination at 6 and 8 weeks can be questioned. The range of titers in sows is wide and the variation in maternal immunity likewise. This situation makes the design of an optimal vaccination programme very complex, since part of the population will respond to early and another part only to late vaccination. The height and variation in sow titers may also explain the clinical situation in farm $\mathrm{C}$, where only part of the fatteners became sick. A similar disease pattern was also observed in farm $\mathrm{A}$ and $\mathrm{B}$ and is actually a common observation in large scale farms in the Philippines. These pigs may not have responded to vaccination at 6 or 8 weeks and have become susceptible during the fattening stage. This study concludes that no standard vaccination programme against CSF exists. More intensive programmes which also include vaccination beyond 8 weeks of age can be suggested under enzootic conditions as present in the Philippines to avoid the disease breakthroughs.

\section{REFERENCES}

1. Biront, P., Leunen, J., and Vandeputte, J. 1987. Inhibition of virus replication in the tonsils of pigs challenged oronasally with classical swine fever. Vet. Microbiol. 14: 105-113.

2. Holm Jensen, M. 1981. Detection of antibodies against hog cholera virus and bovine viral diarrhea virus in porcine serum. Acta Vet. Scand. 22: 85-98.

3. Launais, M., Aynaud, J. M., and Corthier, G. 1978. Hog cholera virus: active immunisation of piglets with the Thiverval strain in the presence and absence of colostral passive immunity. Vet. Microbiol. 3: 31-43.

4. Liess, B. and Prager, D. 1976. Detection of neutralising antibodies: Use of new technical equipment for laboratory swine fever detection. In: EEC Brussels, EUR 5486, 187-197.

5. Moennig, V., Schagemann, G., Dahle, J., Greiserwilke, I., und Leder, L. 1990. A new approach for the diagnosis of hog cholera. Deutsche Tieraerztliche Wochenschrift 97: 91-93.

6. Ogawa, T. and Hatakeyama, H. 1984. Appropriate time for hog cholera vaccination in piglets. In: proc. 8th IPVS, Ghent, Belgium 2: 67.

7. Terpstra, C. and Tielen, M. J. 1976. Antibody response against swine fever following vaccination with C-strain virus. Zentralblad Veterinaermedizin 23: 809-821.

8. Terpstra, C. and Wensvoort, G. 1987. Influence of the vaccination regime on the herd immune response for swine fever. Vet. Microbiol. 13: 143-151.

9. Terpstrac, C. and Wensvoort, G. 1988. The protective value of vaccine induced neutralising antibody titers in swine fever. Vet. Microbiol. 16: 123-128. 